\title{
Proceeding
}

Supplementary Issue: Spring Conferences of Sports Science. Costa Blanca Sports Science Events, 14-15 June 2019. Alicante, Spain.

\section{The winning game in the major football leagues}

\author{
ROBERTO SILVESTRI ${ }^{1}$, FRANCESCO PELUSO CASSESE ${ }^{2}$, GAETANO ALTAVILLA ${ }^{3}$ \\ ${ }^{1}$ University of Salerno, Italy \\ 2University Niccolò Cusano of Rome, Italy \\ 3 University of Split, Croatia
}

\begin{abstract}
The new millennium was marked by the epic of the legendary Barcelona of Guardiola, the coach who revolutionized the world of football with his tiki taka. The search for this game made of fast ball exchanges, continuous changes of position and search for free space to occupy, however, has downgraded what is one of the main technical skills of the game of football, the dribbling. Starting with football schools Pedagogical value of the body and physical activity in childhood. 1vs1 has been set aside to favour other technical fundamentals, so we are in a period where fewer and fewer players take responsibility for trying a game in 1vs1, but prefer to pass the ball to their closest partner. This second study has analysed the scorer rankings of the top 4 European championships (Serie A, Premier League, Spanish League, Bundesliga) of the 2009/2010 and 2017/2018 seasons, taking into account not only the total goals, but also the average shots per game and the average dribbling per game. Keywords: Dribbling; Soccer; Performance analysis; Video analysis.
\end{abstract}

\section{Cite this article as:}

Silvestri, R., Cassese, F.P., \& Altavilla, G. (2019). The winning game in the major football leagues. Journal of Human Sport and Exercise, 14(4proc), S1122-S1127. doi:https://doi.org/10.14198/ihse.2019.14.Proc4.76

Corresponding author. University of Salerno, Italy.

E-mail: R.SILVESTRI7@studenti.unisa.it

Supplementary Issue: Spring Conferences of Sports Science. Costa Blanca Sports Science Events, 14-15 June 2019. Alicante, Spain.

JOURNAL OF HUMAN SPORT \& EXERCISE ISSN 1988-5202

(c) Faculty of Education. University of Alicante doi:10.14198/jhse.2019.14.Proc4.76 


\section{INTRODUCTION}

Football is defined as a situation sport (movements without a repeatability pattern): those sports in which the performance of the sports performance cannot be identified in a simplified periodization of the movements that are performed, due to the presence of one or more opponents(D'Isanto, 2016). Therefore, there is no fixed pattern in time and the independence theorem of simultaneous actions cannot be applied to motion (Raiola, D'santo, 2016). Therefore it cannot be studied through simple actions added together or connected, since the presence of the adversary, which tries to contrast the technique, makes the situation that is created not repeatable, but only classifiable statistically speaking. The study of motion has meaning only on a statistical basis, so it makes no sense to treat the subject through Newtonian physics, but we need to use more efficient and less approximate methods. Therefore, motion must be studied with the methods of statistical physics as a dynamic system. In recent years, even in Italy, as has already been the case for years abroad, terms such as match analysis and performance analysis are increasingly part of the football vocabulary alongside terms such as offside, counterattack, zone defence, etc. Match analysis is a performance analysis tool that aims to provide qualitative and quantitative information on the performance of individual players and the team as a whole. Initially, manual analysis techniques were used based on the annotation of everything that happened during the game, and later on, more and more complex computer systems were used. The use of match analysis by the athletic trainer has certainly widened the definition of the football's performance model. We have moved from the simplistic conception of "alternating aerobicanaerobic sport" to that provided by the proZone system scholars "Calcium is characterized by an intermittent activity with high intensity anaerobic efforts superimposed on low aerobic activity". The objective has therefore shifted from improving aerobic and lactic capacity towards an increase in the ability to perform high intensity sprints for the duration of the race (Ceruso et al, 2019, Gaetano, Rago, 2014). Performance analysis is the study of physical and athletic data and represents the most advanced frontier of the science applied to football, through sophisticated instruments called GPS, the shape of the players is monitored daily and allows to individualize and optimize the work in work out. In recent years it has seen a massive entry of pervasive calculation between sports-related technologies (Izzo et al, 2018), in fact, the detection of physical parameters during training through GPS technology is a portable and economic procedure to monitor workloads (Trocchia et al, 2019). GPS can also provide immediate answers to coaches immediately after the end of the training session (Silvestri, et al, 2018). It is important to consider that the physical profile of football players is very variable, having implications for the interpretation of the high intensity race (Giordano et al, 2019ab), therefore the use of GPS is optimal. The high intensity reached at a certain distance has traditionally been identified as a key indicator of physical performance during games (D'Isanto et al, 2019, Raiola et al. 2018,2019 ) and was related to the state of training (Tiziana et al, 2017). Acceleration and deceleration are the skills that play a key role in professional football, as they represent very demanding energy activities. The enormous demand for acceleration and deceleration phases in football as in basketball, many of which with trajectory changes greater than $30^{\circ}$, leads us to think of the usefulness of using unidirectional running (Altavilla et al, 2017). It is important to know the correlation between the number of successful passes, throws made, the contrasts won and possession of a ball by a team to know its type of game. The research hypothesis consists in the identification of a homogeneity among the teams object of research in the number of successful passages, in the won contrasts, in the shots made and in the possession of the ball. Identify the game setting of the three teams to investigate if there are similarities in the type of setting up the offensive manoeuvre. The teams examined are from the top league football series in Italy, Germany and England. Specifically they are: Juventus, Borussia Dortmund and Liverpool. They were chosen because they reached the first place at the end of the first round in their respective championships. 


\section{METHODS}

The static analysis is based on the regression calculation and the Anova calculation. The data sample is represented by the matches played by the three teams examined. The data for the statistical analysis, and therefore for the calculation of the averages, of the percentages and of the standard deviations, were extrapolated from the videos of the matches examined and compared with the data provided by the InStat site. The researched data are: The team's ball possession time, the total throws made, the goals scored, the number of successful passes and the contrasts won.

\section{RESULTS}

Table 1. Anova test, significance level 0.05. Significance of the three teams in successful passes

\begin{tabular}{lllllll}
\hline ANOVA & & Sum of squares & gl & Quadratic mean & F & Sign. \\
\hline VAR00002 & Between groups & 231054.421 & 17 & 13591.437 & 2.419 & 0.471 \\
& Within the groups & 5618.000 & 1 & 5618.000 & & \\
& Tot & 236672.421 & 18 & & & \\
VAR00003 & Between groups & 257698.132 & 17 & 15158.714 & .384 & 0.875 \\
& Within the groups & 39480.500 & 1 & 39480.500 & & \\
& Tot & 297178.632 & 18 & & & \\
VAR00001 & Between groups & 339200.658 & 17 & 19952.980 & 1.365 & 0.596 \\
& Within the groups & 14620.500 & 1 & 14620.500 & & \\
& Tot & 353821.158 & 18 & & & \\
\hline
\end{tabular}

Table 2. Anova test, significance level 0.05. Significance of the three teams in the shots taken

\begin{tabular}{|c|c|c|c|c|c|c|}
\hline \multicolumn{7}{|l|}{ ANOVA } \\
\hline & & Sum of squares & $\mathrm{gl}$ & Quadratic mean & $\mathrm{F}$ & Sign. \\
\hline \multirow{3}{*}{ VAR00001 } & Between groups & 127.772 & 9 & 14.197 & 0.996 & 0.503 \\
\hline & Within the groups & 128.333 & 9 & 14.259 & & \\
\hline & Tot & 256.105 & 18 & & & \\
\hline \multirow{4}{*}{ VAR00002 } & Between groups & 274.325 & 9 & 30.481 & 5.618 & 0.802 \\
\hline & Within the groups & 48.833 & 9 & 5.426 & & \\
\hline & Tot & 323.158 & 18 & & & \\
\hline & Between groups & 202.789 & 9 & 22.532 & 0.595 & 0.775 \\
\hline \multirow[t]{2}{*}{ VAR00003 } & Within the groups & 341.000 & 9 & 37.889 & & \\
\hline & Tot & 543.789 & 18 & & & \\
\hline
\end{tabular}

Table 3. Anova test, significance level 0.05 . Significance of the three teams in the contrasts won

\begin{tabular}{lllllll}
\hline ANOVA & & & & & \\
\hline & & Sum of squares & gl & Quadratic mean & $\mathrm{F}$ & Sign. \\
\hline VAR00001 & Between groups & 9919.289 & 17 & 583.488 & 1166.975 & 0.023 \\
& Within the groups & .500 & 1 & .500 & & \\
& Tot & 9919.789 & 18 & & & \\
VAR00002 & Between groups & 8141.158 & 17 & 478.892 & 1.222 & 0.622 \\
& Within the groups & 392.000 & 1 & 392.000 & & \\
& Tot & 8533.158 & 18 & & &
\end{tabular}




\begin{tabular}{lllllll} 
VAR00003 & Between groups & 5153.605 & 17 & 303.153 & 5.011 & 0.339 \\
& Within the groups & 60.500 & 1 & 60.500 & & \\
& Tot & 5214.105 & 18 & & & \\
\hline
\end{tabular}

Table 4. Juventus's regression

\begin{tabular}{lllllll}
\hline \multicolumn{7}{l}{ Regression } \\
\hline \multirow{2}{*}{ Model } & \multicolumn{7}{c}{ Non-standardized coefficients } & Standardized coefficients & $\mathrm{t}$ & \multirow{2}{*}{ Sign. } \\
\cline { 3 - 5 } & & $\mathrm{B}$ & Error std. & Beta & & \\
\hline 1 & (Constant) & \#\#\#\# & 9.905 & & 1.034 & .318 \\
& VAR00001 & .322 & .168 & .459 & 1.920 & .074 \\
& VAR00002 & -.005 & .009 & -.143 & -.606 & .554 \\
& VAR00003 & -.007 & .048 & -.035 & -.142 & .889 \\
\hline
\end{tabular}

a. Dependent variable: VAR 04 (Shots made on goal).

b. Predictors: VAR01, VAR02, VAR03 (ball possession, successful passes and defeats won).

Table 5. Borussia Dortmund's regression

\begin{tabular}{|c|c|c|c|c|c|c|}
\hline \multirow{3}{*}{\multicolumn{2}{|c|}{ Model }} & \multicolumn{4}{|c|}{ Regression } & \multirow{3}{*}{ Sign. } \\
\hline & & \multicolumn{2}{|c|}{ Non-standardized coefficients } & \multirow{2}{*}{$\begin{array}{l}\text { Standardized coefficients } \\
\text { Beta }\end{array}$} & \multirow[t]{2}{*}{$\mathrm{t}$} & \\
\hline & & B & Error std. & & & \\
\hline \multirow[t]{4}{*}{1} & (Constant) & 3.446 & 10.121 & & .340 & .738 \\
\hline & VAR00001 & .074 & .166 & .116 & .444 & .664 \\
\hline & VAR00002 & .001 & .008 & .041 & .144 & .887 \\
\hline & VAR00003 & .037 & .047 & .233 & .800 & .436 \\
\hline
\end{tabular}

a. Dependent variable: VAR04 (Shots made on goal).

b. Predictors: VAR01, VAR02, VAR03 (ball possession, successful passes and defeats won).

Table 6. Liverpool's regression

\begin{tabular}{|c|c|c|c|c|c|c|}
\hline \multirow{3}{*}{\multicolumn{2}{|c|}{ Model }} & \multicolumn{3}{|c|}{ Regression } & \multirow{3}{*}{$\mathrm{t}$} & \multirow{3}{*}{ Sign. } \\
\hline & & \multicolumn{2}{|c|}{ Non-standardized coefficients } & \multirow{2}{*}{$\begin{array}{l}\text { Standardized coefficients } \\
\text { Beta }\end{array}$} & & \\
\hline & & $\mathrm{B}$ & Error std. & & & \\
\hline \multirow[t]{4}{*}{1} & (Constant) & -13.037 & 16.342 & & -.798 & .437 \\
\hline & VAR00001 & .286 & .222 & .315 & 1.288 & .217 \\
\hline & VAR00002 & .008 & .010 & .179 & .752 & .463 \\
\hline & VAR00003 & .087 & .080 & .269 & 1.094 & .291 \\
\hline
\end{tabular}

a. Dependent variable: VAR04 (Shots made on goal).

b. Predictors: VAR01, VAR02, VAR03 (ball possession, successful passes and defeats won).

\section{DISCUSSION}

The three teams result, from the Anova tests carried out, homogeneous. There is no significance in the three teams in successful passes, values significantly higher than the significance level 0.05 . There is no evidence of significance in the three teams in the contrasts won, values clearly greater than the level of significance 0.05 . There is no significance in the three teams in the shots taken, values distinctly greater than the significance level 0.05 . The quality of the passages $(0.554)$ and the contrasts won $(0.889)$ have had the greatest impact on the shots made by Juventus, while it has had less influence on ball possession. The quality of the passages $(0,887)$ and the possession of the ball $(0,667)$ have had the greatest effect on the shots taken by Borussia Dortmund, while the defeats have been less affected. The quality of the passages 
has had a greater impact (0.463) on the shots made by Liverpool, while the ball possession $(0.217)$ and the contrasts won (0.291) have had less impact.

\section{CONCLUSION}

The research hypothesis was confirmed by the analysed data. The three groups are homogeneous. It is important to know if there is a correlation between the successful passes, the shots taken and the number of contrasts won so that you can set your game in the best possible way. From the study of the emerged data, and from the video analysis of the games considered, it can be said that Juventus bases its game on pressing and consequently on ball recoveries, combined with a good quality of offensive transition, allows him to create many opportunities by goal. The game of Borussia Dortmund is based on the quality and quantity of ball possession and then reaches the goal thanks to a series of short passes and sudden filtering passes. Liverpool creates its winning actions thanks to high pressing and fast verticalization for high-speed strikers. In anticipation of further future studies these data may be correlated with short passages, long passages, number of successful dribbles, with goals scored from head, right or left and with the number of crosses from right and left. In such a way as to have a good complete view of the dynamics of the construction and the finalization of the game of the teams examined.

\section{REFERENCES}

Altavilla G., Riela L., Di Tore P.A., Raiola G., (2017). The physical effort required from professional football players in different playing positions. Journal of Physical Education and Sport, 17(3):20072012.

D'Isanto, T. (2016) Pedagogical value of the body and physical activity in childhood. Sport Science, 9 (Supplement 2): 13-18.

Gaetano, R., Rago, V. (2014). Preliminary study on effects of hiit-high intensity intermittent training in youth soccer players, Journal of Physical Education and Sport, 14 (2): 148-150.

Raiola, G., D'Isanto, T., D'Elia, F., Altavilla, G. (2019). The evaluation of the improvement of the endurance in the transition period. The European Proceedings of Social \& Behavioural Sciences EpSBS, in press.

Tiziana, D., Antonetta, M., Gaetano, A. (2017). Health and physical activity, Sport Science, 10(1):100105.

D'Isanto, T., D'Elia, F., Raiola, G., Altavilla, G. (2019)Assessment of sport performance: Theoretical aspects and practical indications, Sport Mont, 17 (1), pp. 79-82.

Raiola, G., D'elia, F., Altavilla, G. (2018) Physical activity and sports sciences between European Research Council and academic disciplines in Italy, Journal of Human Sport and Exercise, 13, pp. S283-S295. https://doi.org/10.14198/jhse.2018.13.proc2.13

Raiola, G., D'isanto, T. (2016) Assessment of periodization training in soccer, Journal of Human Sport and Exercise, 11 (Proc1), pp. S267-S278. https://doi.org/10.14198/jhse.2016.11.proc1.19

Gaetano, R., Rago, V. (2014) Preliminary study on effects of hiit-high intensity intermittent training in youth soccer players, Journal of Physical Education and Sport, 14 (2), pp. 148-150.

Giordano, L., Federici, A., Valentini, M., D'elia, F. (2019) Dribbling in football: Confronting learning theories, Journal of Human Sport and Exercise, 14 (Proc2), pp. S228-S232. https://doi.org/10.14198/ihse.2019.14.proc2.10

Ceruso, R., Esposito, G., Federici, A., Valentini, M., D'isanto, T., Preliminary work about the basis data for monitoring youth soccer team planning training(2019) Journal of Human Sport and Exercise, 14 (Proc2), pp. S251-S257. https://doi.org/10.14198//hse.2019.14.proc2.14 
Giordano, L., Federici, A., Valentini, M., D'elia, F. (2019) Dribbling in football: Confronting learning theories Journal of Human Sport and Exercise, 14 (Proc2), pp. S228-S232. https://doi.org/10.14198/ihse.2019.14.proc2.10

Izzo, R., Sopranzetti, S., Hosseini Varde'l, C., Molitierno, G. (2018)Video tracking for the detection of external load to establish proper parameters in elite soccer players during high intensity training, Journal of Physical Education and Sport, 18, art. no. 178, pp. 1199-1202.

\section{(c) (i) (3)}

This work is licensed under a Attribution-NonCommercial-NoDerivatives 4.0 International (CC BY-NC-ND 4.0). 